\title{
Crime and Economic Development in South Africa: A Panel Data Analysis
}

\author{
Submitted 14/03/21, $1^{\text {st }}$ revision 12/04/21, $2^{\text {nd }}$ revision 28/04/21, accepted 25/05/21
}

\section{Leward Jeke, Tafadzwa Chitenderu, Clement Moyo ${ }^{1}$}

\begin{abstract}
:
Purpose: This study aims to determine the effects and impact of crime in South Africa. As economies seek to develop through eliminating inequalities, alleviating poverty, and ensuring economic growth, crime often stands in the way, discouraging investments, fuelling migration, increasing transaction costs, to mention just a few, thereby creating economic development disparities.

Design/Methodology/Approach: To evaluate the economic effects of crime, selected forms of crime are assessed on economic development as measured by economic growth, investments, and property value, among others between the years 1994-2019. To determine the effects and impact of crime, multiple panel regression analysis techniques were employed.

Findings: The Pooled Mean Group technique was utilized in this study, and the results obtained from the econometric modelling indicate that crime has an overall detrimental effect on development. Property crime was found to hurt human development and investment, while contact crime only negatively impacts investments.

Practical Implications: Economic effects of crime have been established using South African data. It is imperative to understand that safety and security is everyone's responsibility to preserve property values, reduce transaction costs, attract investment and economic opportunities for local economic development.

Originality/Value: Limited empirical works exist on evaluating the economic effects of crime. Crime is pertinacious to human nature and society, with variations in the extent and types. Even though education is argued to produce positive externalities through reducing crime, statistics have shown the increasing number of sophisticated crimes that involve welleducated individuals.
\end{abstract}

Keywords: Crime, economic development, Investment, PMG and HDI.

JEL Codes: O11, C10, C23.

Paper Type: Research article.

${ }^{1}$ Nelson Mandela University, Port Elizabeth, South Africa, corresponding author: 


\section{Introduction}

South Africa has been ranked as the 10th most unsafe place globally by the Global Peace Index (Management Study Guide, 2020). The impact of the high crime in South Africa is inevitably high, particularly its impact on its performance. Crime have detrimental effects on the economy, carries costs of law enforcement, and results in loss to businesses (Mahofa et al., 2016; Mtati, 2012; Mauro and Carmeci, 2006). Different crime categories include personal crimes, property crimes, inchoate crimes, statutory crimes, and financial crimes (Justia, 2018). The adverse effects of crime on society include the cost of repairing damages caused, loss of revenue toward running prisons, public resources spent on investigations and arrests, and the trauma, hurt, and pain caused by the individuals directed affected by crime. Crime affects economic activities as it affects investment decisions and other economic variables.

According to Mahofa et al. (2016), crime in South Africa is the most significant constraint of doing business in the country. Compared to most countries, South Africa has a high and notable rate of assaults, murders, rape, and other violent crimes, including xenophobia. Williamson (1957) attributes this high crime in the country to poverty and poor service delivery. According to Justia (2018), other reasons include the normalization and/ subculture of violence in societies, the vulnerability of young people, high levels of inequality and unemployment, and easy access to ammunition and firearms. The crime in South Africa has created an environment that is less conducive to business and economic growth.

The purpose of this study is to investigate the effect of property and contact crime on economic development in South Africa using local data from 1994 to 2019. The economic development indicators chosen are investment and human development index (HDI). The selection of the economic development indicators is based on their close association to the achievement of the socio-economic goals of South Africa. Investment is a significant component of GDP and is linked to job creation. The HDI incorporates development indicators such as health, education, and gross national income (UNDP, 2019). The Pooled Mean Group (PMG) technique proposed by Pesaran, Shin, and Smith (1999) is selected for the empirical analysis. There is scant evidence on the effect of crime on economic development. A significant number of studies investigated the effect of crime on economic growth (Mauro and Carnessi, 2006; Mtati, 2012; Kusuma and Hariyai, 2019). However, economic growth is necessary but insufficient for overall improvements in economic development. Some studies examined the effect of crime on business activities (Kimou, 2015; Mahofa et al., 2016).

Furthermore, some studies suggest that the direction of causality is from economic development (measured by poverty, inequality, and unemployment) to crime (Bhorat et al., 2017). This study incorporates development measures such as the HDI and total investments. Also, it distinguishes between contact and property crime to investigate whether the effect of crime on the different economic development indicators is dependent on the type of crime. 
In what follows, section two provides an overview of crime in South Africa. Section three discusses the relevant theoretical and empirical literature, while section four presents the data and the methodology. Section five presents the empirical results, and section six concludes the study and provides recommendations.

\section{Overview of Crime in South Africa}

According to Mahofa, et al. (2016), crime in South Africa is the greatest constraint of doing business. This has contributed to lower profits, productivity, investor confidence and subsequently hindered economic growth and development (Govender, 2018). Furthermore, crime and violence in homes impact negatively on human capital development by affecting the health of children and their ability to perform well in school. The high crime rate in the country is attributed to socioeconomic issues such as high unemployment rate, poverty levels and inequality (Bhorat et al., 2017). Other reasons include the normalization or a subculture of violence in societies, vulnerability of young people, and the easy access to ammunition and firearms (Justia, 2018). Available data shows that although the number of reported crimes is still high, a downward trend has been recorded over the last few years. Figure 1 shows total crime reported from 2010 to 2019 in South Africa.

This study focuses specifically on the effect of property and contact crime on development indicators. Property crime includes burglary at residential places, which remains the most common crime in South Arica and motor vehicle theft (Bhorat et al, 2017, StatsSA, 2020). Contact crime incorporates murders, sexual assault, attempted murder, common assault, and robbery (Govender, 2018). Around 57 people are murdered in South Africa every day (StatsSA, 2020). The murder rate increased rapidly in the late-1980s and early-1990s. Between 1994 and 2009, the murder rate halved from 67 to 34 murders per 100,000 people. 2011 to 2015, it stabilised to around 32 homicides per 100,000 people although the total number of lives lost has increased due to the increase in population. In the 2016/17 year, the rate of murders increased to 52 a day, with 19,016 murders recorded between April 2016 and March 2017.

Figure 1. Crime Reported in South Africa

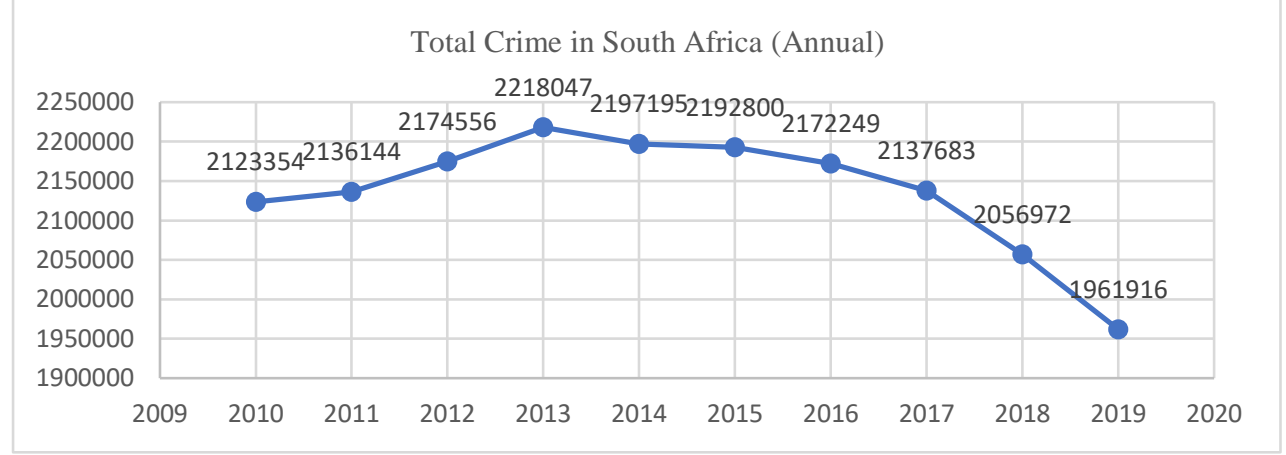

Source: Quantec, 2020. 
The country has one of the highest rates of rape globally, with some 65,000 rapes and other sexual assaults reported for the year ending in March 2012, or 127.6 per 100,000 people in the country (StatsSA, 2020). The incidence of rape has led to the country being referred to as the "rape capital of the world" (Nagtegaal, 2018). South Africa has the highest incidences of child and infant rape in the world (South African Police Service Crime Report 2010/2011). South Africa has a high record of carjacking when compared with other industrialized countries (SAPS Crime Report, 2010/2011). According to the SAPS Crime report 2010/2011, insurance company Hollard Insurance stated in 2007 that they would no longer ensure Volkswagen Citi Golfs, as they were one of the country's most frequently carjacked vehicles.

Figures 2 and 3 highlight the trends in property and contact crime in the different provinces in South Africa between 2010 and 2019. Gauteng almost always records the highest number of crimes of the nine provinces, followed by Western Cape and then KwaZulu Natal (StatsSA, 2020). Figure 2 suggests that property crime has been on a decline in most provinces. However, crime rates remain high, especially in the three provinces mentioned above. Figure 3 shows that contact crime has been rising in provinces such as Gauteng and the Western Cape. In the other provinces, contact crime has remained stagnant with minimal changes.

Figure 2. Trends in property crime

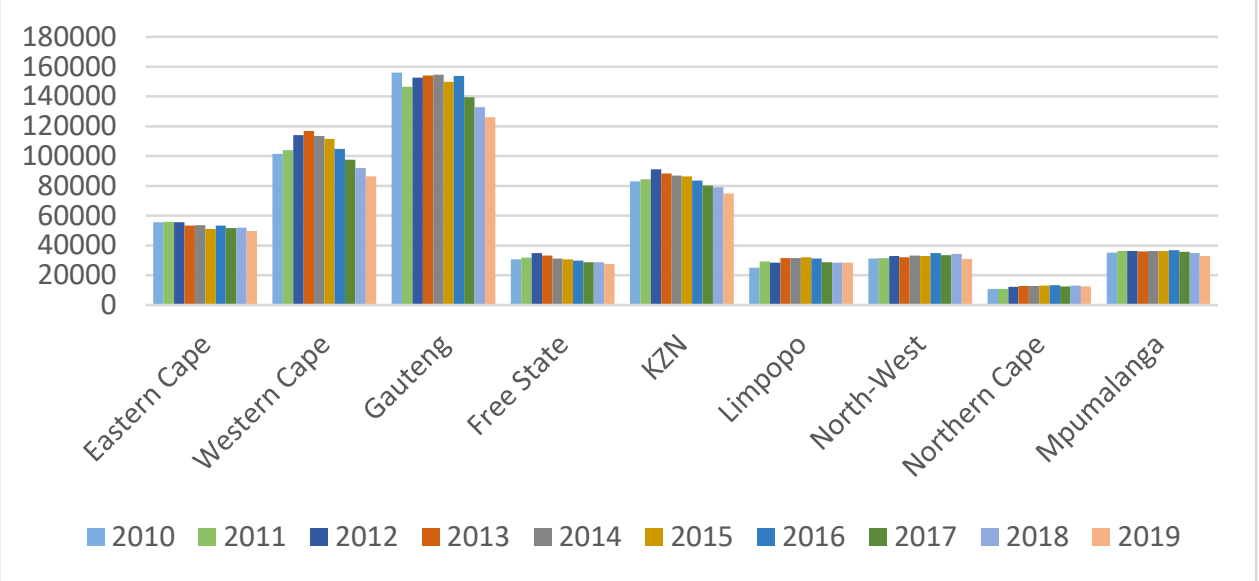

Source: Quantec, 2020.

In Gauteng, for example, the shoplifting and commercial crime category recorded the highest, followed by murder, sexual offenses, assault, and robbery category in 2019. All the other provinces following the same trend. In the year 2020, data published by the South African Police Service (SAPS) and Stats SA indicate that the period from July to September 2020 has recorded an increase in criminal activities across the board compared with the previous period (April to June 2020). It is important to note that during the initial/higher levels of the COVID-19 induced lockdown, criminal activities recorded a massive reduction, particularly during level 5. For example, there was a $72 \%$ reduction in murders and an $81 \%$ reduction in carjacking, and similar 
trends were seen in reported assaults, attempted murders, robbery, and rape (Businesstech, 2020). However, these trends reversed and returned to 'normal' as the lockdown eased, with statistics returning to pre-lockdown levels.

Figure 3. Trends in contact crime

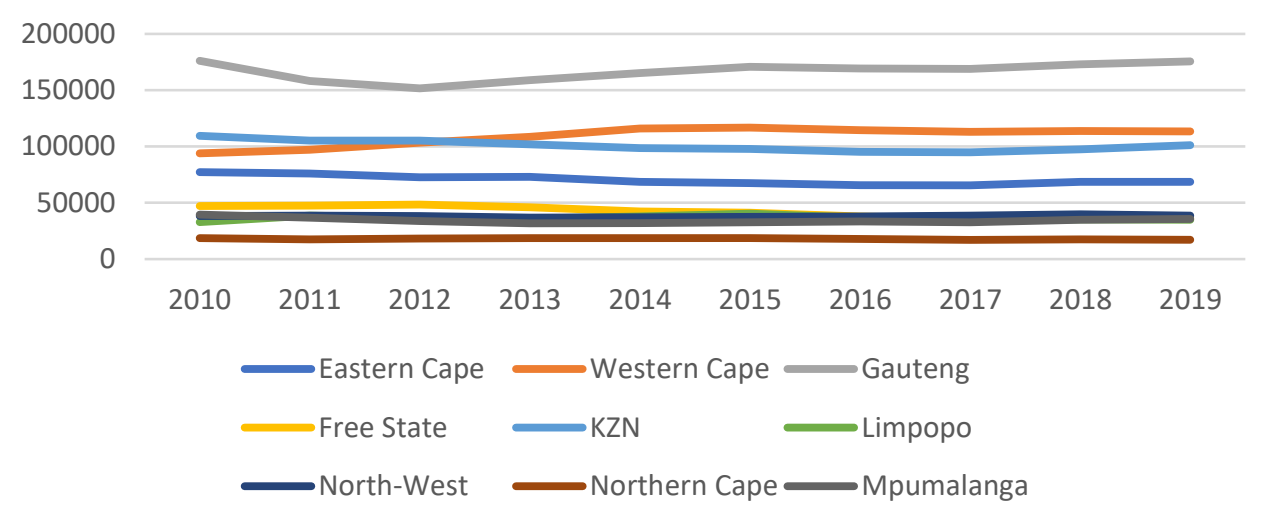

Source: Quantec, 2020.

\section{Literature Review}

The theory of the rational model to crime stipulates that individuals who commit crimes are rational decision-makers who expect to gain from criminal activity, and this gain is greater than the expected costs associated with being caught (Jacob, 2011). Witte and Witt (2002) study the economic theories of crime causation. The Basic theory of economic modelling of criminal behavior is a decision-making model where individuals choose between criminal activity and legal activity based on the expected utility from those acts. It is assumed that individuals participate in criminal activities when the incentives are optimum. The authors list the expected gains from crime relative to earnings from legal work, the chance or risk of being caught and convicted, the extent of punishment, and legal activities' opportunities as factors that influence individuals to engage in criminal activities.

According to Witte and Witt (2002), economic analysis of crime is concerned with incentives on criminal behavior and evaluation of alternative strategies to reduce crime. There are many theories of crime that stem from different study backgrounds. However, there not one theory that adequately explains the impact of crime and all the types of crime. Failure to have a theory that explains the impact of property crime on human development means that this study will integrate all crime theories to understand how different types of crime affect human development.

Rogers (1989) asserts that traditional criminologists believe that crimes essentially offend solid collective sentiments. Crimes happen because individuals have not internalized dominant social norms about proper behavior. On the other hand, Marxist criminologists view crime as acts that offend the perceptions and interests of elites (Rogers, 1989). 
The modernization theory asserts that crime patterns are predictable, and criminality clarifies why criminal behavior in developed countries is characterized by an increase in property crime and a relative decrease in violent crime not associated with property crime (Shelley, 1981). The author further alludes that the rise in the crime rate and its concentration in the urban environment is explained by the greater availability of goods, the increased feasibility of crime commission, and increased feelings of relative deprivation because of a more significant gap between rich and poor or a greater awareness of deprivation due to advertising through the media.

The endogenous growth theory alludes to the importance of a country's domestic absorption. Crime interferes with absorption as it is a cost to the economy. The opportunity cost of running prisons and investigating reported criminal activities using taxpayers' money negatively affects the economic growth rate (Mtati, 2012).

\subsection{Empirical Literature Review}

Although criminal activities are generally known to have detrimental effects on the economy and economic development, few empirical studies have been done to find the effects of crime on significant economic variables. A greater percentage of the research done on crime relates to the variables that affect crime or the impact of different economic variables on crime (Justia, 2018; Mahofa et al., 2016; Mtati, 2012; Mauro and Carmeci, 2006), and no current studies on the causality running from crime to the economic indicators or to economic development to be specific.

Mauro and Carmeci (2006) empirically explored a link between crime, unemployment, and economic growth using Italian regional data. Their findings are no different from the other scholars in that crime imposes a downward pressure on economic growth. Gaibulloev and Sandler (2008) measure the impact of domestic and transnational terrorism on income per capita growth for 1971-2004 in a panel of 18 Western European countries. Their findings suggest that crime has a negative impact on economic growth in these countries.

Rueda and García-Pérez (2015) investigated the impact of crime on private investment in eleven South American countries. They adopted a model to include crime and applied a fixed effect panel data approach using a panel data set from 2000 to 2010 for South American countries. Results indicated that crime affects investment in two levels. First, an increase in the expected cost resulting from crime diminishes private investment, and second, the variance of crime decreases the amount of investment. Kimou (2015) investigated the impact of crime on business activity in Cote d'Ivoire using the World Bank enterprise survey dataset from 26 October 2008 to 20 February 2009 and a Heckman two-step procedure.

This investigation targeted mainly the non-agricultural sector, manufacturing, construction, services and transport, storage, and communication. The research measured business growth in two different ways, accounting profits and volume of investment. It also showed that crime and private provision of security negatively 
impacted firms' profit and investment. The paper concluded that firms with significant assets affected by crime were more likely to pay for security and private security was costly.

Afriyanto (2017) investigated the impact of crime incidence on Foreign Direct Investment (FDI) in Indonesian provinces using panel data covering 31 provinces from 2005 to 2015. The variables of crime used are Total Crime, Property Crime, Violence, Vandalism, Arson, Fraud, Homicides, and Kidnapping. The results indicated that crime variables significantly impact FDI; for every increase in total crime incidence per 100,000 people by ten percent, FDI is expected to decrease by approximately 0.95 percent. The research concluded that government also, among other things, needs to pay attention to minimizing crime incidence in each province as it affects economic development through its effect on FDI.

In a separate study to examine the influence that crimes have on economic growth, Kusuma and Hariyani (2019) used panel data on 31 provinces in Indonesia from 2008 to 2016. To comprehensively analyse this, they used the Human Development Index, investment, level of corruption, and the level of crime as variables against regional Gross Domestic Product. Results obtained indicated that crime, in general, can interfere with economic, political, and security stability activities; results showed a negative correlation between general crimes and regional GDP. The research concluded that crime would reduce GDP and hence economic growth and development in Indonesia.

\subsection{Empirical Literature from South Africa}

Few studies have been conducted in South Africa on the effect of crime. Mtati (2012) investigated the impact of crime on the South African economy and used vector error correction model (VECM), quarterly time-series data (2003-2011), and six variables (crime, actual interest rates, accurate exchange rates, unemployment, poverty, and economic growth). The findings of this study suggest that crime exerts a negative impact on economic growth in the long run in South Africa.

However, according to this study, this relationship is not statistically significant both in the short run and the long run. In another study, Mahofa et al. (2016) analysed the relationship between crime and investment (firm entry) across local municipalities in South Africa using a two-stage least squares estimation method. They used the incidence of crime data sourced from the South African Police Service and a business registration database between 2003 and 2011. Results obtained showed that crime reduces investment as business entry is reduced.

As mentioned earlier, few types of research have been done in South Africa to ascertain the effects of crime on economic variables. As a result, this research aims to bridge this gap by presenting an empirical analysis of the effects of selected types of crime on economic development indicators. 


\section{Data and Methodology}

This section presents the data and outlines the methodological approach of the study. The nine provinces in South Africa are sourced from Quantec's Easy data regional service. The period of the study is 1994 to 2019. Table 1 describes the variables.

Table 1. Description of the data

\begin{tabular}{|l|l|}
\hline Variable & Description \\
\hline GVA & Gross value added \\
\hline INV (Investment) & Gross fixed capital formation \\
\hline CONT (Contact crime) & Total number of crimes against persons \\
\hline PROP (Property crime) & Total number of property related crime \\
\hline HDI & Human development index \\
\hline UNE (Unemployment rate) & $\begin{array}{l}\text { Percentage of the labour force who are } \\
\text { unemployed }\end{array}$ \\
\hline
\end{tabular}

Source: Quantec 2020.

Table 2. Descriptive statistics

\begin{tabular}{|l|r|r|r|r|r|}
\hline Variable & Obs & Mean & Std. Dev. & Min & Max \\
\hline INV & 234 & 49607.113 & 44547.918 & 5692.316 & 213110.74 \\
\hline UE & 234 & 23.365 & 7.566 & 4.734 & 43.472 \\
\hline GVA & 234 & 534936.03 & 479890.07 & 67944.243 & 2211956 \\
\hline HDI & 234 & .595 & .077 & .402 & .754 \\
\hline CONT & 234 & 76613.309 & 52000.76 & 17070.37 & 256817.5 \\
\hline PROP & 234 & 66276.758 & 51595.662 & 10503.96 & 232227.9 \\
\hline
\end{tabular}

Source: Researchers' own computations.

Table 2 outlines the descriptive statistics. Due to their large volatility as measured by the standard deviation, investment, GVA, contact crime and property crime will be used in logarithm form in the regression models.

The empirical analysis is done using a panel data approach, subject to cross-sectional dependence due to unobserved common factors (Henningsen and Henningsen, 2019). Pesaran's (2004) 's cross-sectional dependence test is employed to detect crosssectional dependence. The results of the cross-sectional dependence test presented in Table 3 indicate that the null of cross-sectional dependence is rejected at the $1 \%$ level.

Due to the presence of cross-sectional dependence, the standard first-generation unit root tests and the estimation techniques such as pooled OLS, fixed effects, random effects, and the mean group (MG) estimator are not applicable in this study (Henningsen and Henningsen, 2019). According to Lau et al. (2019), the pooled mean group (PMG) estimator developed by Pesaran et al. (1999) is more efficient in the presence of cross-sectional dependence compared to the conventional tests and thus is utilized in this study. 
Table 3. Cross-sectional dependency test

\begin{tabular}{|l|l|l|l|l|}
\hline Variable & CD-test & P-value & Corr & Abs (Corr) \\
\hline HDI & 27.77 & 0.000 & 0.908 & 0.908 \\
\hline dHDI & 22.04 & 0.000 & 0.735 & 0.735 \\
\hline LINV & 30.22 & 0.000 & 0.988 & 0.988 \\
\hline dLINV & 23.42 & 0.000 & 0.781 & 0.781 \\
\hline UNE & 28.69 & 0.000 & 0.938 & 0.938 \\
\hline dUNE & 29.13 & 0.000 & 0.971 & 0.971 \\
\hline LPROP & 21.27 & 0.000 & 0.695 & 0.695 \\
\hline dLPROP & 17.16 & 0.000 & 0.572 & 0.572 \\
\hline LCONT & 22.10 & 0.000 & 0.722 & 0.722 \\
\hline dLCONT & 21.78 & 0.000 & 0.726 & 0.726 \\
\hline LGVA & 30.43 & 0.000 & 0.995 & 0.995 \\
\hline dLGVA & 19.67 & 0.000 & 0.656 & 0.656 \\
\hline
\end{tabular}

Notes: The null hypothesis is of cross-sectional independence. The test was conducted using the xtdc command created by Eberhardt (2011a). Under the null hypothesis of cross-section independence $C D \sim N(0,1)$. $d$ is the difference operator. $L$ is the logarithm operator.

Source: Researchers'own computations.

Table 4. Pesaran (2007) CIPS unit root test: Levels

\begin{tabular}{|l|l|l|l|}
\hline & & Without Trend & With Trend \\
\hline Variable & Lags & Zt-bar & Zt-bar \\
\hline LGVA & 0 & $-3.559^{* * *}$ & $-3.183^{* * *}$ \\
\hline & 1 & $-2.562^{* * *}$ & $-2.906^{* * *}$ \\
\hline HDI & 0 & 0.803 & 0.536 \\
\hline LPROP & 1 & -0.701 & $-2.816^{* * *}$ \\
\hline & 0 & -0.998 & -0.419 \\
\hline LCONT & 1 & -0.786 & -0.498 \\
\hline & 0 & 0.929 & 1.287 \\
\hline LINV & 1 & -0.314 & 0.410 \\
\hline & 0 & -1.018 & 0.709 \\
\hline UNE & 1 & -2.434 & -1.074 \\
\hline & 0 & 5.715 & 2.229 \\
\hline
\end{tabular}

Notes: *** indicates significance at the $1 \%$ level. The CIPS test was conducted using the Multipurt command created by Eberhardt (2011b).

Source: Researchers' own computations.

The PMG technique requires prior testing of the stationarity properties of the data to confirm the absence of variables integrated of order two (I(2)). Furthermore, tests for cointegration must be employed before estimation using the PMG technique. The CIPS unit root test proposed by Pesaran (2007) is employed for unit root testing due to its ability to cater to cross-sectional dependence. The results are shown in Tables 4 , and 5 indicate that GVA is stationary in levels while the rest of the variables are stationary at first difference. 
Table 5. Pesaran (2007) CIPS unit root test: First difference

\begin{tabular}{|l|l|l|l|}
\hline & & Without Trend & With Trend \\
\hline Variable & Lags & Zt-bar & Zt-bar \\
\hline LGVA & 0 & $-10.790^{* * *}$ & $-9.909 * * *$ \\
\hline HDI & 1 & $-7.640^{* * *}$ & $-6.133 * * *$ \\
\hline & 0 & $-5.215^{* * *}$ & $-3.791^{* * *}$ \\
\hline LPROP & 1 & $-4.035^{* * *}$ & $-2.613^{* * *}$ \\
\hline & 0 & $-9.482^{* * *}$ & $-8.482^{* * *}$ \\
\hline LCONT & 1 & $-5.613 * * *$ & $-4.941 * * *$ \\
\hline & 0 & $-6.322^{* * *}$ & $-4.716^{* * *}$ \\
\hline LINV & 1 & $-3.916^{* * *}$ & $-2.306^{* *}$ \\
\hline & 0 & $-6.333^{* * *}$ & $-4.771^{* * *}$ \\
\hline UNE & 1 & $-6.067 * * *$ & $-4.880^{* * *}$ \\
\hline & 0 & $-5.372 * * *$ & $-4.796^{* * *}$ \\
\hline
\end{tabular}

Notes: *** and ** indicates significance at the $1 \%$ and $5 \%$ levels respectively. The CIPS test was conducted using the Multipurt command created by Eberhardt (2011b).

Source: Researchers' own computations.

\subsection{Model Specification}

The study utilizes a two-equation specification to determine the effect of crime on economic development. The dependent variables or measures of development are the HDI and investment. The models are specified in the form of an ARDL model with one lag as follows:

$\Delta H D I=\beta_{0}+\sum_{i=1}^{p} \beta_{1 i} \Delta H D I_{t-1}+\sum_{i=0}^{p} \beta_{2 i} \Delta L I N V_{t-1}+\sum_{i=0}^{p} \beta_{3 i} \Delta L C R I M E_{t-1}+$

$\sum_{i=0}^{p} \beta_{4 i} \Delta U N E_{t-1}+\alpha_{1 i} H D I_{t-1}+\alpha_{2 i} L_{I N V_{t-1}}+\alpha_{3 i} L C R I M E_{t-1}+\alpha_{4 i} U N E_{t-1}+\varepsilon_{i t}$

$\Delta L I N V=\beta_{0}+\sum_{i=1}^{p} \beta_{1 i} \Delta L I N V_{t-1}+\sum_{i=0}^{p} \beta_{2 i} \Delta L G V A_{t-1}+\sum_{i=0}^{p} \beta_{3 i} \Delta L C R I M E_{t-1}+$

$\sum_{i=0}^{p} \alpha_{1 i} L I N V_{t-1}+\alpha_{2 i} L G V A_{t-1}+\alpha_{3 i} L C R I M E_{t-1}+\varepsilon_{i t}$

where: CRIME represents either contact crime or property crime.

As mentioned above, the PMG technique is selected in this study. The technique assumes that homogenous long-run coefficients and heterogenous short-run coefficients (Pesaran et al., 1999). Other estimators that test the long-run relationship between variables such as the (MG) and Dynamic fixed effects (DFE) will be used for comparison purposes.

\subsection{Empirical Results}

Before estimation by the PMG technique, cointegration is tested using the Pedroni (1999), Pedroni (2004), Kao (1999), and the Westerlund (2007) cointegration tests. The results are presented in Table 6 , and these show that cointegration is detected in two of the three tests for each model specification. It can be concluded that there is a long-run relationship between the variables, and the analysis may proceed to the PMG 
results.

Table 6. Cointegration test

\begin{tabular}{|l|l|l|l|}
\hline Model & \multicolumn{1}{|c|}{ Pedroni Test } & Westerlund test & Kao test \\
\hline $\begin{array}{l}\text { HDI }=\mathrm{f}(\mathrm{INV}, \text { UNE, Property } \\
\text { crime })\end{array}$ & Cointegration & Cointegration & No cointegration \\
\hline $\begin{array}{l}\text { HDI }=\mathrm{f}(\mathrm{INV}, \text { UNE, Contact } \\
\text { crime })\end{array}$ & Cointegration & No Cointegration & Cointegration \\
\hline INV $=\mathrm{f}(\mathrm{GVA}$, Property crime $)$ & Cointegration & Cointegration & No cointegration \\
\hline INV $=\mathrm{f}(\mathrm{GVA}$, Contact crime $)$ & No cointegration & Cointegration & Cointegration \\
\hline
\end{tabular}

Note: The cointegration tests were conducted using the xtcointtest command.

Source: Own creation.

Table 7. HDI and contact crime

\begin{tabular}{|l|l|l|l|}
\hline Variable & PMG & MG & DFE \\
\hline LINV & $0.429(3.53)^{* * *}$ & $0.542(1.82)^{*}$ & $0.539(3.40)^{* * *}$ \\
\hline LCONT & $-0.161(-1.50)$ & $-0.201(-0.40)$ & $-0.021(-0.16)$ \\
\hline UNE & $-0.006(-1.49)$ & $0.003(0.15)$ & $-0.010(-1.89)^{*}$ \\
\hline \multicolumn{4}{|c|}{ Short-run } \\
\hline ECM & $-0.090(-14.27)^{* * *}$ & $-0.079(-5.94)^{* * *}$ & $-0.081(-4.15)^{* * *}$ \\
\hline LINV(-1) & $-0.015(-2.40)^{* *}$ & $-0.014(-1.78)^{*}$ & $-0.019(-1.14)$ \\
\hline LCONT(-1) & $0.018(1.25)$ & $0.018(0.83)$ & $0.008(0.48)$ \\
\hline UNE(-1) & $0.001(1.26)$ & $0.001(1.11)$ & $0.001(1.77)^{*}$ \\
\hline Constant & $-0.18(-10.44)^{* * *}$ & $-0.232(-0.86)$ & $-0.371(-2.17)^{* *}$ \\
\hline
\end{tabular}

Notes: $* * *, * *$ and $*$ indicate significance at the $1 \%, 5 \%$ and $10 \%$ levels respectively.

Figures in parenthesis are $t$-statistics.

Source: Researchers' own computation. Note: Hausman test statistic is 2.38 [0.498].

Table 7 presents the results from the PMG, MG, and DFE techniques for the HDIcontact crime nexus. The PMG technique is superior in the presence of crosssectional dependence, as discussed in the methodology section. Furthermore, the Hausman tests suggest that the PMG is superior to the MG technique (this result is valid for all the regression models). Contact crime has a negative but insignificant effect on human development. The insignificance of the coefficient is also observed in the short run. Unemployment is negatively related to human development. However, the result is insignificant. Investment has a positive and significant impact on human development which confirms theoretical expectations. Investments promote gross national income, which is a significant component of human development. The error correction term is negative and significant, suggesting that $9 \%$ of the disequilibrium is corrected in the first period. The negative sign and significance of the error term indicate model stability and confirm the presence of cointegration between the variables.

Table 8. HDI and property crime

\begin{tabular}{|l|l|l|l|}
\hline Variable & PMG & MG & DFE \\
\hline LINV & $0.431(4.46)^{* * *}$ & $0.437(4.82)^{* * *}$ & $0.453(3.87)^{* * *}$ \\
\hline LPROP & $-0.326(-1.96)^{* *}$ & $-0.504(-3.43)^{* * *}$ & $-0.291(-1.83)^{*}$ \\
\hline
\end{tabular}




\begin{tabular}{|c|c|c|c|}
\hline UNE & $-0.005(-1.33)$ & $-0.003(-1.19)$ & $-0.004(-0.96)$ \\
\hline \multicolumn{4}{|c|}{ Short-run } \\
\hline ECM & $-0.079(-15.56) * * *$ & $-0.085(-7.44)^{* * *}$ & $-0.075(-4.20) * * *$ \\
\hline LINV(-1) & $-0.016(-1.75)^{* *}$ & $-0.018(-1.78)^{*}$ & $-0.017(-0.99)$ \\
\hline LPROP(-1) & $0.046(5.94) * * *$ & $0.056(3.72)^{* * *}$ & $0.051(2.41)^{* *}$ \\
\hline UNE(-1) & $0.001(1.67)^{*}$ & $0.001(1.70)^{*}$ & $0.001(1.97)^{* *}$ \\
\hline Constant & $-0.022(-5.30)^{* * * *}$ & $0.131(0.87)$ & $-0.068(-0.43)$ \\
\hline
\end{tabular}

Note: Hausman test is 0.41 [0.9378)]. ***, ** and * indicate significance at the $1 \%, 5 \%$ and $10 \%$ levels respectively. Figures in parenthesis are $t$-statistics.

Source: Own creation.

Property crime has a negative and significant effect on human development, as shown in Table 8. The negative and significant coefficient of property crime is consistent in all three sets of results. Investment retains its positive and significant effect on human development while unemployment retains its negative and insignificant coefficient.

Tables 9 and 10 show the relationship between investment and contact crime and property crime, respectively. Both types of crime discourage investments, and the coefficients are significant both in the long-run and short-run. This is expected as property crime is detrimental to the business environment and discourages business entry and investments (Mahofa et al., 2016) and (Kimou, 2015). The coefficient of gross value added is positive and significant in the long-run and short-run in both specifications, which confirms that economic growth is a significant driver of domestic investments. The error correction terms in both specifications are negative and significant.

Table 9. Investment and contact crime

\begin{tabular}{|l|l|l|l|}
\hline Variable & PMG & MG & DFE \\
\hline LCONT & $-0.671(-9.64)^{* * *}$ & $-0.574(-9.92)^{* * *}$ & $-0.631(-6.02)^{* * *}$ \\
\hline LGVA & $1.153(23.20)^{* * *}$ & $1.311(9.61)^{* * *}$ & $1.188(15.67)^{* * *}$ \\
\hline \multicolumn{4}{|c|}{ Short-run } \\
\hline ECM & $-0.303(-6.73)^{* * *}$ & $-0.454(-29.28)^{* * *}$ & $-0.259(-6.84)^{* * *}$ \\
\hline LCONT(-1) & $-0.046(-0.64)$ & $0.023(0.27)$ & $-0.054(-0.99)$ \\
\hline LGVA(-1) & $0.664(11.21)^{* * *}$ & $0.354(3.90)^{* * *}$ & $0.649(3.44)^{* * *}$ \\
\hline Constant & $0.942(6.81)^{* * *}$ & $0.175(0.18)$ & $0.576(1.28)$ \\
\hline
\end{tabular}

Note: $* * *$ indicates significance at the $1 \%$ level. Figures in parenthesis are $t$-statistics.

Source: Own creation.

Table 10. Investment and property crime

\begin{tabular}{|l|l|l|l|}
\hline Variable & PMG & MG & DFE \\
\hline LPROP & $-1.469(-6.08)^{* * *}$ & $-1.054(-10.94)^{* * *}$ & $-1.167(-4.31)^{* * *}$ \\
\hline LGVA & $1.591(15.92)^{* * *}$ & $1.172(7.32)^{* * *}$ & $0.921(6.00)^{* * * *}$ \\
\hline \multicolumn{4}{|c|}{ Short-run } \\
\hline ECM & $-0.138(-2.58)^{* * *}$ & $-0.388(-17.15)^{* * *}$ & $-0.174(-5.40)^{* * *}$ \\
\hline LPROP(-1) & $-0.040(-0.25)$ & $0.217(2.03)^{* *}$ & $0.002(0.001)$ \\
\hline LGVA(-1) & $0.823(4.55)^{* * *}$ & $0.453(4.74)^{* * *}$ & $0.817(4.33)^{* * *}$ \\
\hline Constant & $0.764(2.55)^{* *}$ & $2.771(3.40)^{* * *}$ & $1.967(3.20)^{* * *}$ \\
\hline
\end{tabular}

Note: Hausman test: 4.91 [0.086]. *** and ** indicate significance at the $1 \%$ and $5 \%$ levels respectively. Figures in parenthesis are $t$-statistics.

Source: Own creation. 


\subsection{Implications of the Results}

The empirical results have profound implications for South Africa, a country battling quadruple challenges of low economic growth, high unemployment, poverty, and inequality. To solve these challenges, policymakers have sought to promote small businesses, encourage domestic and foreign investments, and enhance human capital levels. The high crime rate is detrimental to human development and investment in the country and thus a significant hindrance to achieving the socio-economic goals. Both contact crime and property crime are detrimental to economic development. However, the results suggest that property crime is more harmful. Bhorat et al. (2017) show that property crime contributes more to total crime compared to other forms of crime.

High crime rates discourage business start-ups and small businesses' growth as they are forced to enhance their expenditures on security, which in turn increases the cost of operations (Bureau for Economic Research, 2016). The increase in operating costs uses up funds that could have been invested in growing a business. High crime rates hurt human development through child abuse, reduced education expenditures, and limited access to healthcare (Heinemann and Verner, 2006). Therefore, South Africa should employ measures to reduce crime levels to promote human development, which is a significant determinant of the achievement of socio-economic goals of poverty alleviation, unemployment, and inequality reduction.

\section{Conclusion}

The impact of crime is of interest to any economy as it may bring detrimental effects and derail efforts to develop economies. This research aimed at investigating the effects of crime in the regions in South Africa on economic development indicators between the periods 1994 and 2019. Crime has had an adverse effect on the country's economic performance as estimates suggest that it consumes 19\% of GDP. The high crime rate in the country is attributed to socioeconomic issues such as high unemployment rate, poverty levels, and inequality (Bhorat et al., 2017). Other reasons include the normalization or a subculture of violence in societies, vulnerability of young people, and easy access to ammunition and firearms (Justia, 2018).

The PMG technique was utilized in the study, and the results obtained from the econometric modelling conducted indicate that crime has an overall detrimental effect on development. Property crime negatively affects both human development and investment, while contact crime only negatively impacts investments. As such, it can be deduced that property crime is more harmful to economic development. The results support Mahofa et al. (2016) and Kimou (2015), who found that crime affects business entry and investments.

It is recommended that policymakers introduce measures to reduce the crime rate to attract investment and create a conducive environment for development. Considering the socioeconomic challenges faced by the country, the reduction in the high crime 
rate is of paramount importance given its negative effect on investment by the private sector and the accumulation of human capital. The study by Bhorat et al. (2017) highlighted that the socioeconomic challenges in South Africa are significant determinants of crime. Therefore, left unchecked, the high crime rate will perpetuate the vicious cycle of high poverty, unemployment, and inequality levels, which will encourage more crime.

\section{References:}

Afriyanto, M.M. 2017. The impact of crime on foreign direct investment. Economic Journal of Emerging Markets, 9(2), 189-198.

Bhorat, H., Lilenstein, A., Monnakgotla, J., Thornton, A., van der Zee, K. 2017. The socioeconomic determinants of crime in South Africa: An empirical assessment. Development Policy Research Unit. DPRU, University of Cape Town.

Bureau for Economic Research. 2016. The small, medium, and micro enterprise sector of South Africa. Research Note No. 1.

Businesstech. 2020. South Africa's Latest Crime Statistics-Everything you need to Know. https://www.businesstech.co.za.

Eberhardt, M. 2011a. XTCD: Stata module to investigate Variable/Residual Cross-Section Dependence.

Eberhardt, M. 2011b. MULTIPURT: Stata module to run 1st and 2nd generation panel unit root tests for multiple variables and lags. Statistical Software Components.

Gaibulloev, K., Sandler, T. 2008. Growth consequences of terrorism in Western Europe. KYKLOS, 61(3), 411-424.

Govender, D. 2018. Contact and Property Related Crimes in South Africa: Need for Strategies and Democratic Policing. International Journal of Criminal Justice Sciences, 13(1), 55-67.

Heinemann, A., Verner, D. 2006. Crime and violence in development: a literature review of Latin America and the Caribbean. World Bank Policy Research Working Paper 4041. Retrieved from: https://openknowledge.worldbank.org/handle/10986/9024 License: CC BY 3.0 IGO.

Henningsen, A., Henningsen, G. 2019. Analysis of Panel Data Using R. In: Panel Data Econometrics (ed.). Academic Press, 345-398.

Jacob, A. 2011. Economic theories of crime and delinquency. Journal of Human behavior in the Social Environment, 21, (3), 270-283.

Justia. 2018. Types of Criminal Offenses. Retrieved from: https://www.justia.com/criminal/offenses.

Kao, C. 1999. Spurious regression and residual-based tests for cointegration in panel data. Journal of Econometrics, 90(1), 1-44.

Kimou, A.J.C. 2015. Crime, Self-Protection, and Business Growth in Cote d'Ivoire. Modern Economy, 6(1), 1101-1114.

Kusuma Hendra, H.F.H., Hidayat, W. 2019. The Relationship Between Crime and Economics Growth in Indonesia. KnE Social Sciences, 3(13), 1105-1113.

Lau, L.S., Ng, C.F., Cheah, S.P., Choong, C.K. 2019. Chapter 9 - Panel Data Analysis (Stationarity, Cointegration, and Causality). In: Özcan, B., Öztürk, I. (eds.) Environmental Kuznets Curve (EKC). Academic Press, 101-113.

Mahofa, G., Sundaram, A., Edwards, L. 2016. Impact of Crime on Firm Entry: Evidence from South Africa. ERSA working paper 652. Retrieved from: 
https://www.econrsa.org/system

/files/publications/working_papers/working_paper_652.pdf.

Management Study Guide (MSG). 2020. Impact of Crime on South African Economy.

Retrieved from: https://www.managementstudyguide.com/impact-of-crime-onsouth-african-economy.htm.

Mauro, L., Carmeci, G. 2006. A Poverty Trap of Crime and Unemployment. Review of Development Economics, 11(3), 450-462.

Mtati, N.J. 2012. The impact of crime on the South African economic growth. Retrieved from:

http://vital.seals.ac.za:8080/vital/access/manager/Repository/vital:9131?site_nam $\mathrm{e}=$ GlobalV

iew\&exact=sm_creator\%3A\%22Mtati\%2C+Nokuzola+Julia\%22\&sort=sort_ss_t itle $\% 2 F$.

Nagtegaal, J. 2018. Surge in sexual assault and violence has led to South Africa being dubbed "the rape capital of the world. Retrieved from:

https://southcoastherald.co.za/314591/surge-sexual-assault-violence-led-southafrica-dubbed-rape-capital-world/.

Pedroni, P.1999. Critical values for cointegration tests in heterogeneous panels with multiple regressors. Oxford Bulletin of Economics and statistics, 61(S1), 653-670.

Pedroni, P. 2004. Panel cointegration: asymptotic and finite sample properties of pooled time series tests with an application to the PPP hypothesis. Econometric theory, 20(3), 597-625.

Pesaran, M., Hashem, S.Y., Smith, R.P. 1999. Pooled Mean Group Estimation of Dynamic Heterogeneous Panels. Journal of the American Statistical Association, 94(446), 621-634.

Pesaran, M.H. 2004. General diagnostic tests for cross-sectional dependence in panels. University of Cambridge, Cambridge Working Papers in Economics No. 435.

Pesaran, M.H. 2007. A simple panel unit root test in the presence of cross-section dependence. Journal of Applied Econometrics, 22(2), 265-312.

Quantec, 2020. EasyData. Retrieved from: https://www.quantec.co.za/easydata/.

Rogers, J.D. 1989. Theories of crime and development: An historical perspective. The Journal of Development Studies, 25(3), 314-328.

Rueda, R.A.A., García-Pérez, M.I. 2015. The Price of Crime: How Crime Affects Private Investment in South America, Revista Economía y Región, Universidad Tecnológica de Bolívar, 9(2), 47-74.

Shelley, L.I. 1981. Crime and modernization: The impact of industrialization and urbanization on crime, Southern Illinois University Press.

South African Police Service Crime Report. 2010/2011. Retrieved from: https://www.saps.gov.za.

StatsSA. 2020. Governance, public safety, and justice survey GPSJS 2019/20. Retrieved from: http://www.statssa.gov.za/publications/P0341/P03412019.pdf.

UNDP. 2019. Human Development Report 2019. Beyond income, beyond averages, beyond today: Inequalities in human development in the 21st century. New York.

Retrieved from: http://hdr.undp.org/en/content/human-development-report-2019.

Westerlund, J. 2007. Testing for error correction in panel data. Oxford Bulletin of Economics and statistics, 69(6), 709-748.

Williamson, R.C. 1957. Crime in South Africa: Some Aspects of Causes and Treatment. Journal of Criminal Law and Criminology, 48(2), 185-192.

Witte, A.D., Witt, R. 2002. Crime causation: economic theories. In: Encyclopaedia of Crime and Justice, MacMillan Reference Library, 302-306. 